\title{
CONCEPTUAL THEORETICAL MODEL FOR LIFE CYCLE ENERGY ANALYSIS OF PHOTOVOLTAIC MODULES
}

\author{
Milovan Medojevic, Ilija Cosic, Nemanja Sremcev, Milovan Lazarevic
}
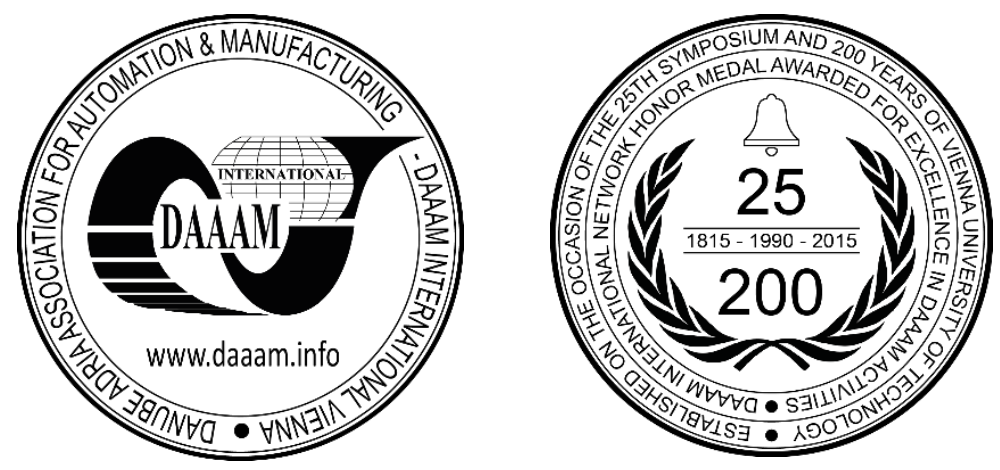

This Publication has to be referred as: Medojevic, M[ilovan]; Cosic, I[lija]; Sremcev, N[emanja] \& Lazarevic, M[ilovan] (2016). Conceptual Theoretical Model for Life Cycle Energy Analysis of Photovoltaic Modules, Proceedings of the 27th DAAAM International Symposium, pp.0534-0543, B. Katalinic (Ed.), Published by DAAAM International, ISBN 978-3-902734-08-2, ISSN 1726-9679, Vienna, Austria

DOI: $10.2507 / 27$ th.daaam.proceedings.079

\begin{abstract}
Photovoltaic (PV) systems, as well as other renewable energy systems, strive to be both energy efficient and cost competitive in order to emerge as a prominent mode of electricity production. However, conversion efficiency, defined as the percentage of solar insolation converted to electricity, has been one of the primary performance metrics for evaluating alternative PV technologies. Unfortunately, conversion efficiency only addresses the operational energy efficiency of a PV device. A more comprehensive energy analysis includes the total life-cycle of the PV system, encompassing raw material production, manufacturing, use, maintenance, and end-of-life management. Having this in mind, the aim of this paper is to provide a closer insight on the energy consumption intensity of the relevant processes from resource production processes to the end of life management of PV modules. In this paper a theoretical, conceptual and above all holistic model for life cycle energy analysis has been introduced and analysed, while the crucial process points, relevant in terms of energy recovery are identified and presented.
\end{abstract}

Keywords: PV module; Life cycle energy analysis; Energy consumption.

\section{Introduction}

With average annual growth rates in excess of $40 \%$ over the past decade [1,2], the success of the PV industry can largely be attributed to the steadfast growth of wafer-based multi-crystalline and mono-crystalline silicon. This growth has been sustained through a powerful combination of three critical competitive advantages: (1) industry-leading full module area sunlight power conversion efficiencies (to date, monocrystalline silicon continues to provide the highest power conversion efficiency among all commercially demonstrated single junction PV modules [3]); (2) product 'bankability' from the appropriately qualified suppliers (with warranties for $80 \%$ of original performance after 25 years of service now being standard [4,5]); and (3) a consistent ability to offer competitively priced modules, which has been enabled through an ability to realize cost reductions throughout the c-Si module supply chain. In addition, PV technology offers some unique benefits that are not realized by other renewable energy technologies, such as the fact that it represents a silent energy source which in most cases does not require moving parts [6]. Furthermore, PV's have a long system lifetime with low maintenance costs with experienced substantial reduction in upfront cost over the past two decades. Being a decentralized technology, PV systems increase the resilience of the energy infrastructure, while simultaneously 
improving national security of supply. This ascertainment constitutes support and points to the importance of research in this area.

Having in mind the aforementioned, determination of production system energy performance and efficiency could be identified by implementation of the life cycle energy analysis (LCEA). Conventionally, life cycle analysis (LCA) takes into account the direct and indirect impacts throughout the entire life cycle of the product, including material sourcing, manufacturing, operation, transportation, disposal, etc. Moreover, as given by many authors, such as Phylipsen [7], Alsema [8], Knapp [9], Phent [10], Meijer [11], LCA is recognized as an invaluable tool to assess the energy and environmental profiles of a PV systems in practice for many years. Likewise, LCEA is an approach to energy management system implementation involving the quantitative evaluation of a product's overall energy performance and impact. Energy requirements throughout the whole life cycle of the product are estimated in order to enable such evaluation and provide results that can be used for related energy analysis and assessment. On the other hand, since life cycle is related to a broad range of variables and is complicated, it is difficult to comprehend the exact significance of the results, where, accordingly, it is highly important to define a purpose for the evaluation.

However, a majority of studies dealing with this issue, lacks a holistic approach in determination of energy payback time and intensity of energy consumption of a typical PV system. In the most studies, the system boundary is defined as the pre-manufacturing, manufacturing, installation and use phases, while recycling and disposal phases are excluded $[12,13]$. Furthermore, in some cases boundary conditions for analysis only take into account energy consumption of specific quartz sand-to-PV module manufacturing processes [14,15]. Likewise, a shortage of studies that takes into account inter process/operation transportation energy consumption, as well as energy consumed during distribution and logistics phase (before putting the system in operation) has been identified.

Therefore, in this paper, LCEA principles are suggested as a mean for overall efficiency identification regarding crystalline-based PV technology, where a more comprehensive energy analysis includes the total life-cycle of the PV system, encompassing raw material production, manufacturing, use, maintenance, inter process/operation energy consumption, and end-of-life management. This has been concretely and in detail given as a conceptual theoretical model, while it is strongly believed that application of this model ensures systematic monitoring of a system process defined by implied system boundaries.

\section{Conceptual model for PV module life cycle energy analysis}

Having in mind that the objective of this study was to implement the LCEA approach for identifying and guiding the PV modules life cycle, a detailed description of the LCEA methodology and its application is presented as conceptual theoretical model. Even though the analysis could be deeper and more complex it stimulates logical identification for potential optimization spots, system effectiveness and process energy efficiency.

\subsection{Defining the system boundaries}

By respecting that the system boundaries should be defined with careful consideration, the scope of the analysis is to evaluate the total energy requirements for the observed system scope level (OSSL), where OSSL considers the complexity and how detailed the system should be analysed.

The manufacturing of solar cells, to produce electrical power, is quite complex and involves many steps starting from the initial grains of sand to the finished solar cell module or panel, it utilization and end of life treatment. (Fig. 1).

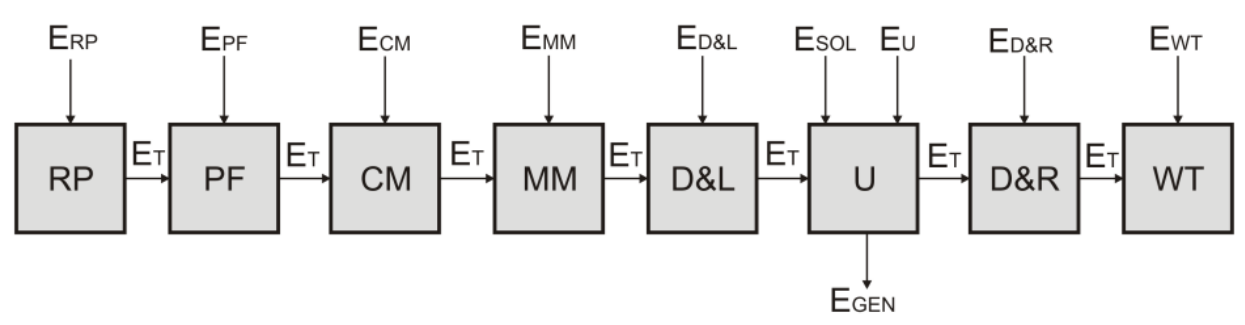

Fig. 1. Observed system scope level and overall process flow

In this study, the manufacturing process is roughly divided into sub categories where some of them are consisted of specific actions and often represent separate processes that in some cases can be outsourced. This also applies to the product end of life treatment processes respectively. However, it is of high importance to establish the important physical components or subsystems for both energy and production systems that play a key role in the supply and demand side of overall process operation. When energy and process flowcharts are put together, valuable information is provided on where, why and what type of energy is used. This represents the basis for decisions on setting up energy cost centres (ECC), segments (i.e. units of equipment or single equipment) where activities or production volume are quantifiable and where a significant amount of energy is used [16]. Given the aforementioned, this model identifies key processes in a PV 
module life cycle as an ECC's upon which general energy balance equation could be generated and derived depending on research complexity. The Fig. 1 illustrates the OSSL, where:

RP - Resource production process
PF - Part fabrication process
CM - Cell manufacturing process
MM - Module manufacturing process
D\&L - Distribution and logistics
U - Utilization
D\&R - Disassembly and Recycling
WT - Waste treatment
$E_{T}-$ Inter-process transportation energy consumption
$E_{R P}-$ RP Energy consumption

\author{
$\mathrm{E}_{\mathrm{PF}}-\mathrm{PF}$ Energy consumption \\ $\mathrm{E}_{\mathrm{CM}}-\mathrm{CM}$ Energy consumption \\ $\mathrm{E}_{\mathrm{MM}}-\mathrm{MM}$ Energy consumption \\ $\mathrm{E}_{\mathrm{D} \& \mathrm{~L}}-\mathrm{D} \& \mathrm{~L}$ Energy consumption \\ $\mathrm{E}_{\mathrm{SOL}}$ - Solar gains (Insolation) \\ $\mathrm{E}_{\mathrm{U}}-\mathrm{U}$ Energy consumption \\ $\mathrm{E}_{\mathrm{GEN}}-$ Generated energy \\ $E_{D \& R}-D \& R$ Energy consumption \\ $\mathrm{E}_{\mathrm{WT}}-\mathrm{WT}$ Energy consumption
}

In order to determine overall system energy consumption $\left(\mathrm{E}_{\mathrm{sys}}\right)$, energy inputs for each stage of the life-cycle in the lifetime period are stated in Equation (1):

$$
\mathrm{E}_{\mathrm{sys}}=\mathrm{E}_{\mathrm{RP}}+\mathrm{E}_{\mathrm{PF}}+\mathrm{E}_{\mathrm{CM}}+\mathrm{E}_{\mathrm{MM}}+\mathrm{E}_{\mathrm{D \& L}}+\mathrm{E}_{\mathrm{U}}+\mathrm{E}_{\mathrm{D \& R}}+\mathrm{E}_{\mathrm{WT}}+\sum \mathrm{E}_{\mathrm{T}}
$$

In addition, energy payback time (EPBT), a metric adopted by several analysts to characterize the energy sustainability of various technologies could be introduced to identify overall energy profitability of observed system. It is the energy analogy to financial payback, defined as the time necessary for a photovoltaic panel to generate the energy equivalent to that used to produce it. In this case EPBT can be determined as given in the Equation (2):

$$
\mathrm{EPBT}=\frac{\mathrm{E}_{\mathrm{sys}}}{\mathrm{E}_{\mathrm{GEN}}}
$$

Considering all previously mentioned, the same approach is applied to identified subcategories based on defined research boundaries given in the Fig. 1.

\title{
2.2 Resource production
}

The basic, starting material for solar cells manufacturing is silicon. Silicon is an important resource and semiconductor which is extremely brittle. Resource production process (RP) represents its manufacturing (Fig. 2) by heating quartz sand with the coke at a high temperature in an electric furnace and then processed to metallurgical grade silicon with a purity of about $99 \%$. The silicon is then refined in a complex purification step involving the intermediate trichlorosilane. Polycrystalline silicon ingots are then moulded from the crystalline silicon granules (solar-grade silicon).

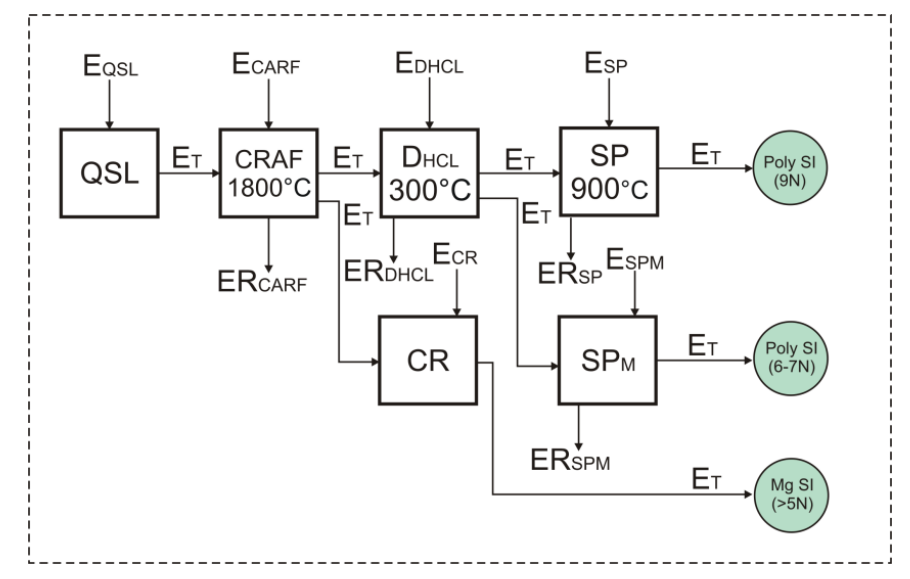

Fig. 2. Resource production process flow

In the Fig. 2 it is possible to distinct three main categories of silicon manufacturing processes, resulting in different purity levels: (1) Electronic-grade silicon (9N), (2) Medium-grade silicon (6-7N) and (3) Metallurgical-grade silicon $(>5 \mathrm{~N})$. At the beginning, quartz sand is imported via quartz sand loader (QSL), for which, it is need to ensure adequate amount of energy $\left(\mathrm{E}_{\mathrm{QSL}}\right.$ ). Then, quartz sand is transported to the next operation which indicates that transportation energy consumption (ET) should be also taken into account. The next step is coke reduction (CRAF) where metallurgical-grade silicon with $98.5 \%$ purity is produced from quartz sand in an arc furnace at very high temperatures. Here the high temperature $\left(1800^{\circ} \mathrm{C}\right)$, necessary for process execution, is provided by electric arc furnace, which indicates significant 
power draw of the furnace and thereby energy consumption $\left(\mathrm{E}_{\mathrm{CARF}}\right)$. Having in mind the height of temperature which must be reached, potential of energy recovery should be considered. In this case, system modification and upgrade with heat exchangers could ensure that the certain amount of energy could be recovered (ER $\mathrm{CARF}_{\text {) }}$ and used in the next process step or for heating, hot water preparation, as well as for other heat-demanding processes. After coke reduction, the metallurgical grade silicon powder is dissolved in hydrogen chloride $\left(\mathrm{D}_{\mathrm{HCL}}\right)$ and subsequently distilled to form a saline gas. In most instances, this is the trichlorosilane, but could be others. This process is 6 times less energy intensive in compared to CRAF since it requires temperature of $300^{\circ} \mathrm{C}$. This thermal energy ( $\left.\mathrm{E}_{\mathrm{DHCL}}\right)$ could be largely provided as $\left(\mathrm{ER}_{\mathrm{CARF}}\right)$, if it does not disturb the functioning of the system. Next in a row is so-called Siemens Process (SP) where the polycrystalline silicon is grown at quite high temperatures $\left(900^{\circ} \mathrm{C}\right)$. It requires hydrogen and produces more hydrogenchloride as a by-product. Similarly to previously mentioned CARF, significant power draw occur indicating energy consumption $\left(\mathrm{E}_{\mathrm{SP}}\right)$, while at the same time potential for energy recovery becomes obvious (ER $\left.\mathrm{R}_{\mathrm{SP}}\right)$. The Siemens Process is the last step in production of electronic-grade silicon $(9 \mathrm{~N})$. In addition, the big drawback of the standard process as described above is that a Siemens reactor is very expensive and the Siemens process itself requires a lot of energy. A number of new proprietary processes reduce the energy consumption and the capital costs for silicon production, though they are still similar to the traditional Siemens process. These are so called modified Siemens processes ( $\left.\mathrm{SP}_{\mathrm{M}}\right)$ where two main alternatives are imposed. The first one is Fluidized Bed Reactor which operates at much lower temperatures and does not produce by-products, while the second one is Vapour to liquid deposition which is similar to Siemens, but ensures faster extraction. In both cases medium-grade silicon $(6-7 \mathrm{~N})$ is produced. However, $\mathrm{SP}_{\mathrm{M}}$ also consume energy $\left(\mathrm{E}_{\mathrm{SPM}}\right)$ and therefore it is equally important to analyse potential for energy recovery $\left(\mathrm{ER}_{\mathrm{SPM}}\right)$. Lastly, in an altogether different process, metallurgical-grade silicon is chemically refined (CR). By blowing gasses through, the silicon melts, the boron and phosphorous impurities are removed, followed by directional solidification. Energy consumption of CR is defined as $\left(\mathrm{E}_{\mathrm{CR}}\right)$, while taking this production route metallurgical-grade silicon $(>5 \mathrm{~N})$ is generated. However, it could be concluded that by avoiding high purification, manufacturing costs could be reduced significantly [17].

In order to determine RP consumption $\left(E_{R P}\right)$, energy inputs $\left(E_{i}\right)$ for each process stage are summed up while energy recovery potential (ER) which could be reused or reapplied is subtracted from the inputs sum. This has been given below by Equations (3) and (4):

$$
\begin{aligned}
& \mathrm{E}_{\mathrm{RP}}=\sum \mathrm{E}_{\mathrm{i}}-\sum \mathrm{ER} \\
& \mathrm{E}_{\mathrm{RP}}=\mathrm{E}_{\mathrm{QSL}}+\mathrm{E}_{\mathrm{CARF}}+\mathrm{E}_{\mathrm{DHCL}}+\mathrm{E}_{\mathrm{CR}}+\mathrm{E}_{\mathrm{SP}}+\mathrm{E}_{\mathrm{SPM}}+\sum \mathrm{E}_{\mathrm{T}}-\left(\mathrm{ER}_{\mathrm{CARF}}+\mathrm{ER}_{\mathrm{DHCL}}+\mathrm{ER}_{\mathrm{SP}}+\mathrm{ER}_{\mathrm{SPM}}\right)
\end{aligned}
$$

Here the Equation (4) could be derived more, which is not necessary to understand this model in theory, while model practical application generate more precise results by increasing research complexity level.

\subsection{Part fabrication}

Part fabrication process (PF) or "wafering" is where the ingots are firstly cut to small bricks and then to thin quadratic slices, so called wafers (Fig. 3). The cutting of silicon wafers is one of the most difficult parts of the entire machining process.

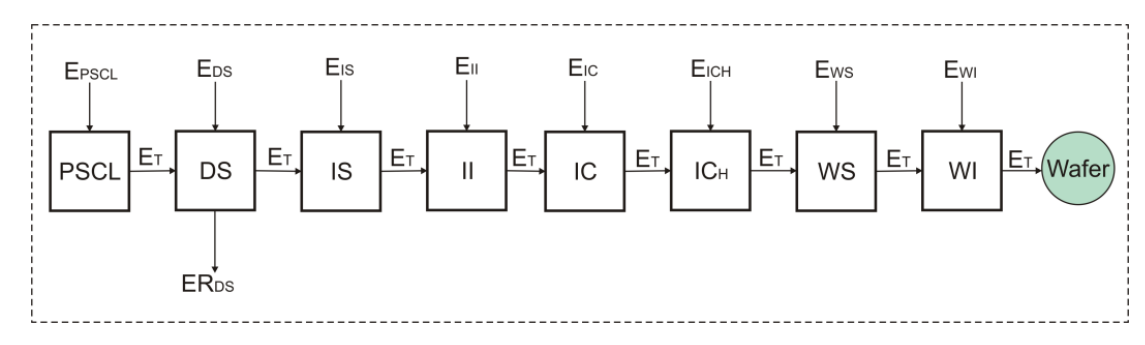

Fig. 3. Part fabrication process flow

Polycrystalline silicon is a material that consists of multiple small silicon crystals. The manufacture method is to solidify the melting silicon (to get the polycrystalline silicon ingots, the melting silicon will be casted via slowly cooling from bottom to top in the squared crucible, then the ingots are being cut in bricks and finally sliced into wafers). Process starts by importing Poly Si chunk via Poly Si chunk loader (PSCL) and consumes energy (EPSC). Then, in the next step directional solidification occur (DS) where the melting silicon will be casted via slowly cooling from bottom to top in the squared crucible in order to generate silicon ingot. Having in mind the energy intensity of melting silicon ( $\left.E_{D S}\right)$, during the cooling process a certain amount of energy could be recovered $\left(\mathrm{ER}_{\mathrm{DS}}\right)$. Furthermore, generated ingots are being squared (IS) by engaging required energy ( $\mathrm{E}_{\mathrm{IS}}$ ), and inspected (II) in order to identify possible fractures and irregularities. Inspection of ingots is not as energy intensive process as previously presented ones but still requires electricity ( $\left.\mathrm{E}_{\mathrm{II}}\right)$ for its operation. Inspected ingots that meet the desired quality are forwarded to cropping (IC) and then to chamfering (IC $\mathrm{H}_{\mathrm{H}}$ ), 
while the $\left(\mathrm{E}_{\mathrm{IC}}\right)$ and $\left(\mathrm{E}_{\mathrm{ICH}}\right)$ represent the energy consumption of these processes respectively. Lastly, final-shaped ingots are cut in bricks and sliced into wafers (WS) after which wafers are inspected to meet the required quality (WI). Here energy consumption of wafer slicing operation is presented as $\left(\mathrm{E}_{\mathrm{WS}}\right)$, while energy consumption of final wafer inspection is $\left(\mathrm{E}_{\mathrm{WI}}\right)$.

According to the same principle adopted to determine energy consumption of RP given in the Equation (4), PF energy consumption is given in the Equation (5):

$$
\mathrm{E}_{\mathrm{PF}}=\mathrm{E}_{\mathrm{PSCL}}+\mathrm{E}_{\mathrm{DS}}+\mathrm{E}_{\mathrm{IS}}+\mathrm{E}_{\mathrm{II}}+\mathrm{E}_{\mathrm{IC}}+\mathrm{E}_{\mathrm{ICH}}+\mathrm{E}_{\mathrm{WS}}+\mathrm{E}_{\mathrm{WI}}+\sum \mathrm{E}_{\mathrm{T}}-\mathrm{ER}_{\mathrm{DS}}
$$

As already mentioned regarding the Equation (4), Equation (5) could be derived more as well, depending on the research complexity.

\subsection{Cell manufacturing}

In the cell manufacturing process (CM), a functional solar cell is produced from the wafer. Cell production is a multistep physical-chemical process which includes variety of important steps such as doping, the anti reflex coating and electrical contacts soldering (Fig. 4).

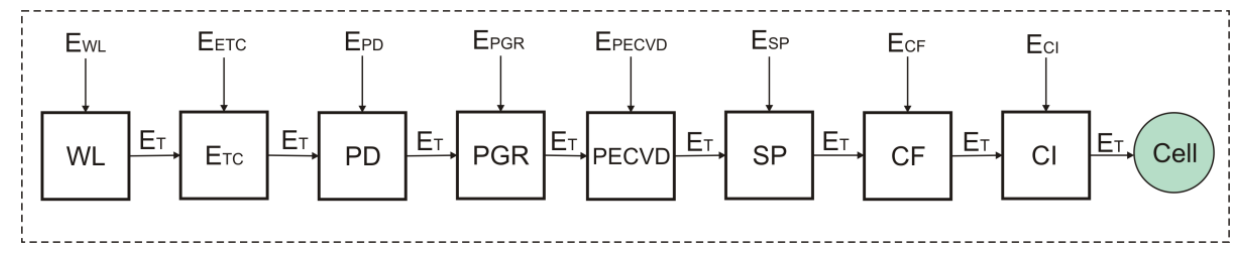

Fig. 4. Cell manufacturing process flow

Cell manufacturing process starts by wafer loading (WL) and cleaning by using acid or alkali liquid to do saw damage removal, and in order to perform work, it will consume certain amount of energy $\left(\mathrm{E}_{\mathrm{WL}}\right)$. The next step is so called etching or texture forming $\left(\mathrm{E}_{\mathrm{TC}}\right)$, where acid or alkali liquid is used to form texture and consumes $\left(\mathrm{E}_{\mathrm{ETC}}\right)$ amount of energy for operation. Coming up next, Phosphorus Diffusion (PD) occur under high temperature vacuum tube process with gas $\left(\mathrm{POCl}_{3}\right)$ to define positive/negative electric junctions, where $\left(\mathrm{E}_{\mathrm{PD}}\right)$ represent $\mathrm{PD}$ energy consumption. Upon completion of PD, phosphorus glass removal (PGR) process, also known as Wet Edge Isolation, starts by using acid liquid in order to remove $\mathrm{SiO}_{2}$ layer from wafer surface and isolate wafer edge. Next stage in the process flow is the Plasma Enhanced Chemical Vapour Deposition (PECVD) where anti-reflection layer (SiNx) is built on wafer surface. After that, screen printing operation (placing the electrode pattern on both side with metal component paste) starts (SP) followed by operation called co-firing $(\mathrm{CF})$, where high temperature heater is used to make cross-link between electrode and junction for electric current output. After CF, solar cells are inspected (CI) by surface visual inspection with AOI (automated optical inspection) and electricity with IV-tester [18]. All of the previously mentioned operations (PGR, PECVD, SP, CF and $\mathrm{CI}$ ) are accompanied by specific energy consumptions ( $\mathrm{E}_{\mathrm{PGR}}$, $\mathrm{E}_{\mathrm{PECVD}}, \mathrm{E}_{\mathrm{SP}}, \mathrm{E}_{\mathrm{CF}}, \mathrm{E}_{\mathrm{CI}}$ ) respectively, where the cell manufacturing process energy consumption $\left(\mathrm{E}_{\mathrm{CM}}\right)$ represents the sum of energy inputs at this process stage as given by Equation (6):

$$
\mathrm{E}_{\mathrm{CM}}=\mathrm{E}_{\mathrm{WL}}+\mathrm{E}_{\mathrm{ETC}}+\mathrm{E}_{\mathrm{PD}}+\mathrm{E}_{\mathrm{PGR}}+\mathrm{E}_{\mathrm{PECVD}}+\mathrm{E}_{\mathrm{SP}}+\mathrm{E}_{\mathrm{CF}}+\mathrm{E}_{\mathrm{CI}}+\sum \mathrm{E}_{\mathrm{T}}
$$

\subsection{Module manufacturing}

In the module manufacturing process (MM), the solar cell has its characteristic appearance and ability to convert the sunlight into electrical power. Likewise, CM in MM, the solar cells are assembled to ready-for-use modules. Several solar cells are connected together to form solar modules in order to generate a useful amount of electrical power. The MM process flow is shown in the Fig. 5.

The process of module manufacturing starts by loading solar cells in the solar cell loader (SCL), where the ( $\left.\mathrm{E}_{\mathrm{SCL}}\right)$ represents the amount of energy needed to perform the operation. Next operation considers tabbing and stringing (TS), after which cells are being laid up by automatic cell lay-up machine (AL). This is followed by energy consumption ( $\mathrm{E}_{\mathrm{TS}}$ ) and $\left(\mathrm{E}_{\mathrm{AL}}\right)$ respectively. In addition, the laid up cells are forwarded to bus bar soldering (BBS) and electrical inspection $(\mathrm{EI})$, while analogously to previous processes $\left(\mathrm{E}_{\mathrm{BBS}}\right)$ and $\left(\mathrm{E}_{\mathrm{EI}}\right)$ represent energy consumption of these operations. Furthermore, after EI, cells enter the laminator (L). Lamination is one of the most critical processes in the solar module manufacturing line which ensures the quality and durability of the PV module. The lamination main function is module encapsulation by applying the right pressure and temperature to laminate the various components. This is energy intensive process $\left(E_{L}\right)$, after which cells are being cooled down, which indicates the potential for energy recovery $\left(E_{L}\right)$. 


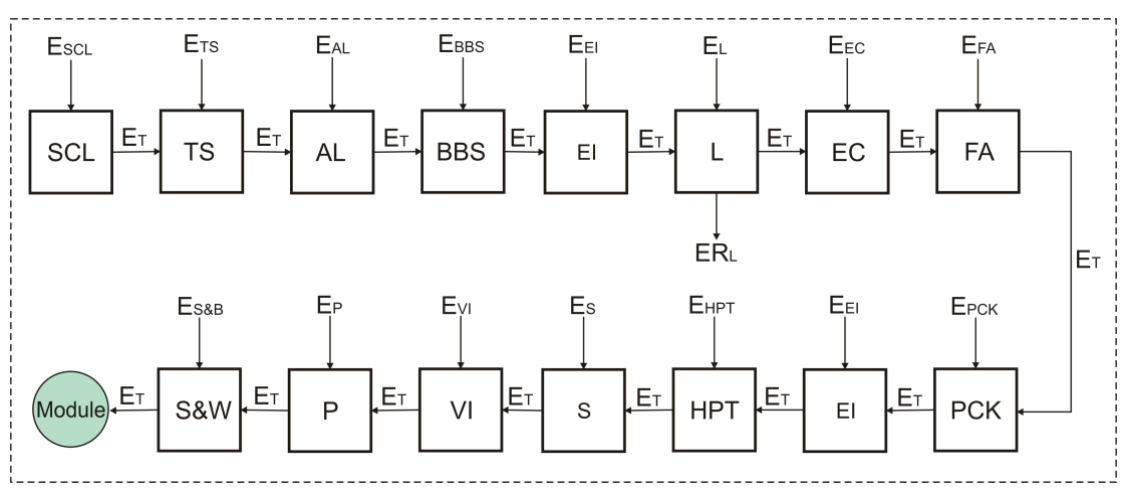

Fig. 5. Module manufacturing process flow

Next operations are edge cutting (EC) and frame assembly (FA), followed by so called punching (PCK) where corner key is being placed. These operations are followed by $\left(\mathrm{E}_{\mathrm{EC}}\right),\left(\mathrm{E}_{\mathrm{FA}}\right)$ and $\left(\mathrm{E}_{\mathrm{PCK}}\right)$ energy consumption in order to perform desired tasks. After PCK, EI is conducted again, and cells are forwarded to Hi-pot testing (HPT). Traditionally, HPT is a term given to a class of electrical safety testing instruments used to verify electrical insulation in finished appliances, other wired assemblies, printed circuit boards, etc. HPT is low energy intensity process $\left(\mathrm{E}_{\mathrm{HPT}}\right)$, but for the sake of consistency it should be taken into account [19]. The following operations, simulation (S), visual inspection (VI), packiging $(\mathrm{P})$, as well as storage and warehousing $(\mathrm{S} \& \mathrm{~W})$ represent the final operations in the module manufacturing process while their energy consumption by individual operation are given as $\left(\mathrm{E}_{\mathrm{S}}\right),\left(\mathrm{E}_{\mathrm{VI}}\right),\left(\mathrm{E}_{\mathrm{P}}\right),\left(\mathrm{E}_{\mathrm{S} \& W}\right)$ respectively.

MM process energy consumption ( $\mathrm{E}_{\mathrm{MM}}$ ) could be determined as given in Equation (7):

$$
\mathrm{E}_{\mathrm{CM}}=\mathrm{E}_{\mathrm{SCL}}+\mathrm{E}_{\mathrm{TS}}+\mathrm{E}_{\mathrm{AL}}+\mathrm{E}_{\mathrm{BBS}}+2 \mathrm{E}_{\mathrm{EI}}+\mathrm{E}_{\mathrm{L}}+\mathrm{E}_{\mathrm{EC}}+\mathrm{E}_{\mathrm{FA}}+\mathrm{E}_{\mathrm{PCK}}+\mathrm{E}_{\mathrm{HPT}}+\mathrm{E}_{\mathrm{S}}+\mathrm{E}_{\mathrm{VI}}+\mathrm{E}_{\mathrm{P}}+\mathrm{E}_{\mathrm{S} \& \mathrm{~W}}+\sum \mathrm{E}_{\mathrm{T}}-\mathrm{ER}_{\mathrm{L}}
$$

\subsection{Logistics and distribution}

Here, logistics is considered as the finalized solar modules flow management between the point of origin and the point of destination in order to meet arranged requirements of customers or corporations. Especially the core logistics task, transportation of the goods, can reduce costs and energy consumption through efficient energy management [20,21]. The relevant factors are the choice of means of transportation, duration and length of transportation and cooperation with logistics service providers. Roughly, the logistics causes more than $14 \%$ percent of $\mathrm{CO}_{2}$ emissions worldwide [22]. In addition, an often case during distribution is warehousing where the products are being stored before being finally distributed to customers. Having in mind that logistic processes can be quite complex, as well as that variety of logistic models exists today, it was not analysed in detail as previous process in this study. However, in order to determine energy consumption, a specific distribution and logistics model should be identified upon which overall energy consumption $\left(E_{D \& L}\right)$ could be determined. This process has been briefly shown in the Fig. 1.

\subsection{Utilization process}

The utilization of PV modules in order to generate electricity is the most diverse process in the LCEA. This observation follows from the fact that this process primarly generates energy in compared to the all aformentioned ones which were more or less intensive energy consumers. Although here energy consumption is also present, it is insignificant compared to the amount of generated energy during operation period. The utiliziation process (U) of PV modules is illustratively given in the Fig. 6.

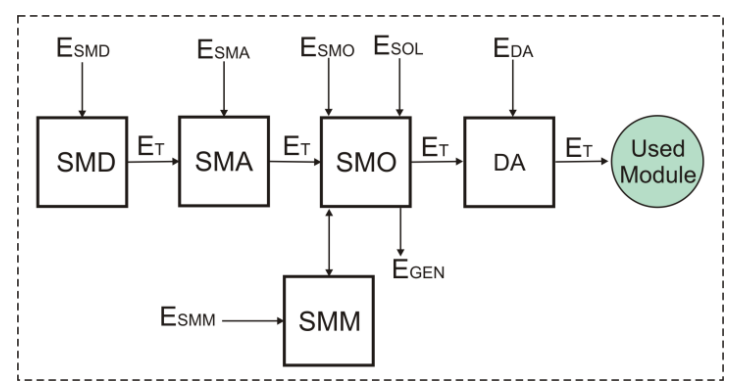

Fig. 6. Utilization process flow

The process starts by distributing solar modules (SMD) to the assembly location where the modules are being assembled (SMA) and prepared for operation phase. In order to complete the operations, a certain energy had to be 
consumed. These are presenteted as $\left(\mathrm{E}_{\mathrm{SMD}}\right)$ and $\left(\mathrm{E}_{\mathrm{SMA}}\right)$ respectively in the Fig. 6. Next phase is PV module operating phase. This phase represents the crucial phase for the LCEA as given by Equation (2), where EPBT is in inverse proportion to the $\left(\mathrm{E}_{\mathrm{GEN}}\right)$. The general method to estimate the $\left(\mathrm{E}_{\mathrm{GEN}}\right)$ in output of a PV system is given in Equation (8):

$$
\mathrm{E}_{\mathrm{GEN}}=\mathrm{A} \cdot \eta \cdot \mathrm{E}_{\mathrm{SOL}} \cdot \mathrm{P}_{\mathrm{R}} \cdot \tau[\mathrm{kWh} / \mathrm{a}]
$$

The $\left(\mathrm{E}_{\mathrm{GEN}}\right)$ represents a function of total solar panel area $\left(\mathrm{A},\left[\mathrm{m}^{2}\right]\right)$, solar panel yield or efficiency $(\eta,[\%])$, annual average solar radiation on tilted panels $\left(\mathrm{E}_{\mathrm{SOL}},\left[\mathrm{kWh} / \mathrm{m}^{2} / \mathrm{a}\right]\right)$ and performance ratio or losses coefficient integration $\left(\mathrm{P}_{\mathrm{R}},[\%]\right)$ over lifecycle operation time $(\tau,[\mathrm{h}]$ ). In addition, $\eta$ is the yield of the solar module given by the ratio of electrical power (in $\mathrm{kWp}$ ) of one module divided by its area. For example, the solar panel yield of a PV module of $250 \mathrm{Wp}$ with an area of $1.6 \mathrm{~m}^{2}$ is $15.6 \%$. It is important to mention that this nominal ratio is given for standard test conditions (insolation: 1000 $\mathrm{W} / \mathrm{m}^{2}$, cell temperature: $25^{\circ} \mathrm{C}$, wind speed: $1 \mathrm{~m} / \mathrm{s}$, Reference Solar Spectral Irradiance at Air Mass: 1.5$)$. ESOL is the annual average solar radiation on tilted panels. $\mathrm{E}_{\mathrm{SOL}}$ is highly determined by PV system location and varies between 200 $\left(\mathrm{kWh} / \mathrm{m}^{2} / \mathrm{a}\right)$ in Norway and $2600\left(\mathrm{kWh} / \mathrm{m}^{2} / \mathrm{a}\right)$ in Saudi Arabia. Lastly, PR (Performance Ratio) is a very important value to evaluate the quality of a photovoltaic installation because it gives the performance of the installation independently of the orientation, inclination of the panel, etc. PR value depends on the site location, technology, sizing of the system, etc., while it function is to include overall system losses such as Inverter losses (4\% to $10 \%)$, Temperature losses (5\% to $18 \%)$, DC cables losses (1 to 3\%), AC cables losses (1 to 3\%), Shadings ( $0 \%$ to $80 \%$ specific to each site), Losses at weak radiation (3\% to $7 \%)$, Losses due to dust and snow coverage ( $\leq 2 \%)$, as well as other possible losses (?\%) [23].

An example of typical PV on-grid system components with energy transformation flow is given in the Fig. 7. It consists of 15 modules attached into 2 strings ( 7 and 8, $250 \mathrm{Wp}$, modules per string), $3.6 \mathrm{kWp}$ Inverter, connected via 6 and 4 $\mathrm{mm}^{2} \mathrm{PV}$ solar cables. The effective capacity of this single phase PV solar system ammounts $3.75 \mathrm{kWp}$ [24].

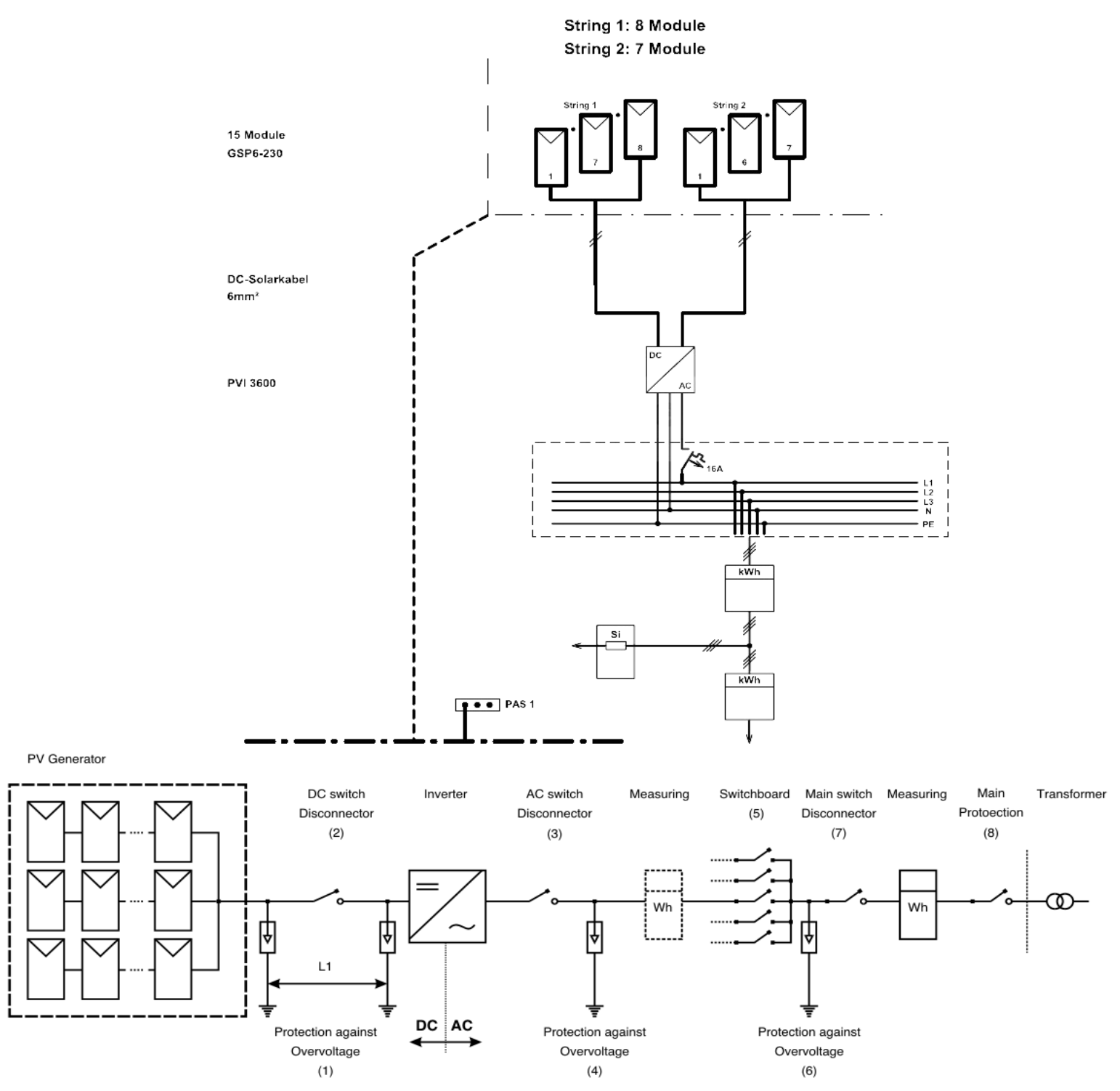

Fig. 7. Typical PV on-grid system components and energy transformation flow [24] 
Having in mind the process flow given in the Fig. 8. usefull or better said accountable $\left(\mathrm{E}_{\mathrm{GEN}}\right)$ is amount of energy handed over to the grid.

If the system operation life time is 25 years, overall energy that has been generated $\left(\mathrm{E}_{\mathrm{GO}}\right)$ by the PV system could be determined as given in the Equation (9):

$$
E_{G O}=\sum_{a=1}^{a=25} E_{G E N}=\sum_{a=1}^{a=25} A \cdot \eta \cdot E_{S O L} \cdot P_{R} \cdot \tau
$$

During the operation period all the maintenance time occurred due to the system failure or disconnection, should be subtracted from $\left(\mathrm{E}_{\mathrm{GO}}\right)$, because system or part of the system had not been productive during that period. Solar module maintenance $(\mathrm{SMM})$ is accompanied by maintenance energy consumption $\left(\mathrm{E}_{S M M}\right)$, which in case of large PV power plants can be pretty intensive. After operation life cycle ends, solar modules are being disassembled (DA) and transported to the storage, from which they are being forwarded to disassembly and recycling processes. Transportation energy consumption $\left(E_{\mathrm{T}}\right)$, as well as disassembly energy consumption $\left(\mathrm{E}_{\mathrm{DA}}\right)$, are illustratively shown in the Fig. 6.

According to the all previously mentioned, energy consumption of (U) is given in the Equation (10):

$$
E_{U}=E_{S M D}+E_{S M A}+E_{S M O}+E_{S M M}+E_{S D A}+\sum E_{T}
$$

Likewise, Equation (11) stands for overall energy production $\left(\mathrm{E}_{\mathrm{P}}\right)$ of the $(\mathrm{U})$ process individually:

$$
\mathrm{E}_{\mathrm{P}}=\mathrm{E}_{\mathrm{GO}}-\mathrm{E}_{\mathrm{U}}
$$

\subsection{Disassembly, Recycle and Waste Treatment process}

An example of PV disassembling and recycling technology that enables the automatic separation consists of three main processes such as aluminium frame removal, backsheet removal, EVA (ethylene-vinyl-acetate) resin burning. This has been illustratevly given in the Fig. 8 .

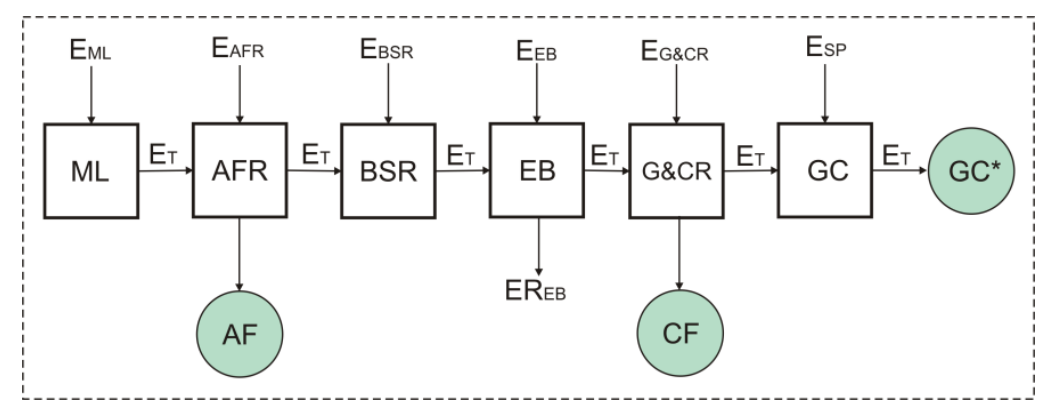

Fig. 8. Disassembly and Recycle process flow

The process starts by loading modules by module loader (ML) after which modules are directed to the operation of automatic frame removal (AFR), where aluminum frames (AF) are being separated and stored. Here, $\left(\mathrm{E}_{\mathrm{ML}}\right)$ and $\left(\mathrm{E}_{\mathrm{AFR}}\right)$ represent the energy consumption of mentioned operations respectively. Next operation is back sheet removal (BSR) followed by EVA film burning (EB). Unlike the BSR, which is only characterized by its energy consumption ( $\mathrm{E}_{\mathrm{BSR}}$ ), EB has the potential to partly recover $\left(E_{\mathrm{EB}}\right)$ energy consumed $\left(\mathrm{E}_{\mathrm{EB}}\right)$ for the incineration of EVA film burning. Next in a row is glass and cell recovery $(\mathrm{G} \& \mathrm{CR})$ where cell fragments are separated, while the glass is forwarded to the glass crusher (GC) in order to produce glass cullet $\left(\mathrm{GC}^{*}\right)$ [25]. These are being followed by their specific energy consumption ( $\left.\mathrm{E}_{\mathrm{G} \& \mathrm{CR}}\right)$ and $\left(\mathrm{E}_{\mathrm{GC}}\right)$ respectively.

Conclusively, all components of PV modules are being separated as much as possible in order to recover and recycle valuable materials, so they can be handed out to companies which refine metals and recycle secondary metals. Likewise, glass that can be separated and retain high purity is recycled as glass cullet. Lastly, materials difficult or unable to separate, recover and recycle are being sent to landfill. Depending on subject to regulation and classification of hazardous content, appropriate waste treatment process (WT) is applied where process energy consumption ( $\left.\mathrm{E}_{\mathrm{WT}}\right)$, as well as the possibility of energy recovery should be taken into account or considered. According to the all previously mentioned, energy consumption of (D\&R) is given in the Equation (12):

$$
\mathrm{E}_{\mathrm{R} \& \mathrm{D}}=\mathrm{E}_{\mathrm{ML}}+\mathrm{E}_{\mathrm{AFR}}+\mathrm{E}_{\mathrm{BSR}}+\mathrm{E}_{\mathrm{EB}}+\mathrm{E}_{\mathrm{G} \& \mathrm{CR}}+\mathrm{E}_{\mathrm{GC}}+\mathrm{E}_{\mathrm{WT}} \sum \mathrm{E}_{\mathrm{T}}-\left(\mathrm{ER}_{\mathrm{EB}}+\mathrm{ER}_{\mathrm{WT}}\right)
$$




\section{Discussion}

Having in mind that LCEA is a fundamental tool for evaluating and guiding the development of PV technology, comprehensive modelling of a PV system is essential for assessing its full potential as a sustainable energy technology. The model equations presented here, provide a means for evaluating the life-cycle energy performance of a PV system. On the other hand, this paper emphasises a conceptual theoretical model development in order to generate a holistic approach for LCEA of PV systems. As previously mentioned, even though the analysis could be more complex the purpose of this study is to stimulate logical identification of potential optimization spots, system effectiveness and process energy efficiency by respecting carefully defined system boundaries. It is important to mention that the boundaries of the system under investigation are variable depending on the specific scope and objectives of each analysis.

Moreover, carefully conducted LCEA could be considered as major input for Energy payback time determination. This metric assesses the time period necessary for a PV project to become profitable from an energy perspective.

Furthermore, electricity production efficiency should be the metric of choice when comparing competing electricitygenerating systems. The maximum electricity production efficiency of a PV system is a function of its useful life, so this metric can evaluate the lifetime energy performance of an electricity-generating system. Energy payback time, in contrast, does not address ultimate efficiency of the system being measured.

Likewise, life-cycle conversion efficiency is a useful metric for directly comparing alternative solar technologies because it measures how efficiently a system converts sunlight into net energy in the form of electricity. Life-cycle conversion efficiency allows another meaningful comparison between various PV devices, such as crystalline and amorphous silicon modules.

By applying this conceptual model in practice, systematic approach to problem solving could be ensured, while the observation complexity could be derived to the desired or needed level.

A more refined model would enable the evaluation of metrics based on cases where energy input requirements are met by PV electricity-generating systems or other renewable sources. Such a model would require material production energy, manufacturing energy and other energy inputs to be disaggregated into specific renewable and non-renewable categories. Substitution of electricity for other energy carriers, such as natural gas and fuel oil, could also be considered. This scenario may result in a situation where the substitution leads to more primary energy consumption than the conventional fuels case. For example, an electrically heated boiler is less efficient on a primary energy basis than a natural gas boiler, resulting in higher total energy consumption.

\section{Conclusion}

The increasing demand for renewable energy challenges society to find out sustainable and renewable energy source. In this quest, LCEA is imposed as a tool which can be used effectively in assessing the sustainability of renewable energy sources, such as PV systems, while, on the other hand, the collection of actual data for such study is a quite challenging task.

This paper provides a holistic approach regarding PV system energy consumption and generation over the useful life time. In addition, potential energy recovery spots have been identified, but these still represent the subject of change in terms of technology differentiation. Practical implementation of this model combined with multi-objective analysis of environmental, performance, cost and regulatory/policy issues over the life-cycle of a PV system could ultimately provide the most complete basis for design, planning and implementation. This full set of information and data offers a more powerful means for promoting PV technology as an effective source of sustainable energy.

Recognizing this goal, LCEA remains one of the most fundamental components of a multi-objective analysis of an energy-generating system.

\section{References}

[1] Frankl, P., Nowak, S., Gutschner, M., Gnos, S., Rinke, T. (2010). International Energy Agency Technology Roadmap: Solar Photovoltaic Energy, Available Online at: http://www.iea.org/papers/2010/pv_roadmap.pdfS.

[2] Mints, P. (2011). Photovoltaic Manufacturer Shipments, Capacity and Competitive Analysis 2010/2011. Navigant Consulting Photovoltaic Service Program: Report NPS-Supply 6, Palo Alto, CA.

[3] Smith, D.D., Cousins, P.J., Masad, A., Westerberg, S., Johnson, M., Tu, X., Dennis, T., Harley, G., Solomon, G., Rim, S., Shepherd, M., Herrington, S., Defensor, M., Leygo, A., Tomada, P., Wu, J. (2012). Sunpower's generation III high-efficiency lower-cost technology: transition to full-scale manufacturing, in: Proceedings of the Thirty eighth IEEEP VSC,2012.

[4] Trina Solar Linear Performance Warranty (3.5\% in the first year, thereafter $0.68 \%$ per year, ending with $80.18 \%$ in the 25th year after the Warranty Start Date). Available online at: http://www.trinasolar.com/eu/products/product-resources/product-warrantyS.

[5] Goodrich, A., Hacke, P., Wang, Q., Sopori, B., Margolis, R., James, T.L., Woodhouse, M. (2013). A wafer-based monocrystalline silicon photovoltaics road map: Utilizing known technology improvement opportunities for further reductions in manufacturing costs. Solar Energy Materials \& Solar Cells, 114, pp. 110-135. 
[6] Bhandari, K.P., Collier, J.M., Ellingson, R.J., Apul D.S. (2015). Energy payback time (EPBT) and energy return on energy invested (EROI) of solar photovoltaic systems: A systematic review and meta-analysis. Renewable and Sustainable Energy Reviews, 47, Jul 2015., pp. 133-141, ISSN: 1364-0321.

[7] Phylipsen, G.J.M., Alsema, E.A. (1995). Environmental life cycle assessment of multicrystalline silicon solar cell modules. Report, 95057, Department of Science Technology and Society of Utrecht University (STS-UU), Netherlands. Available online at: www.chem.uu.nl/nws/www/publica/95057.htm.

[8] Alsema, E.A. (2000). Energy pay-back time and $\mathrm{CO}_{2}$ emissions of PV systems. Progress in Photovoltaics: Research and Applications, 8, pp. 17-25.

[9] Knapp, K.E., Jester, T.L. (2000) Energy balances for photovoltaic modules: status and prospects. in IEEE Photovoltaics specialists conference. Available online at: www.ieeepvsc.nrel.gov.

[10] Pehnt, M., Bubenzer, A., Räuber, A. (2002) Life-Cycle Assessment of Photovoltaic Systems - Trying to fight Deepseated Prejudices. Photovoltaics Guidebook for Decision Makers, Springer: Berlin, DE.

[11] Meijer, A., Huijbregts, M.A.J., Schermer, J.J., Reijnders, L. (2003). Life-cycle Assessment of Photovoltaic Modules: Comparison of mc-Si, InGaP and InGaP/mc-Si Solar Modules. Progress in Photovoltaics: Research and Applications, 11, pp. 275-287. DOI: 10.1002/pip.489.

[12] Hyoungseok, K., Kyounghoon, C., Fthenakis, V.M., Parikhit, S., Hur, T. (2014). Life cycle assessment of cadmium telluride photovoltaic (CdTe PV) systems. Solar Energy, 103, pp. 78-88.

[13] Peng, J., Lu, L., Yang, H. (2013). Review on life cycle assessment of energy payback and greenhouse gas emission of solar photovoltaic systems. Renewable and Sustainable Energy Reviews, 19, pp. 255-274.

[14] Sherwani, A.F., Usmani, J.A., Varun, C. (2010). Life cycle assessment of solar PV based electricity generation systems: A review. Renewable and Sustainable Energy Reviews, 14, pp. 540-544.

[15] Stoppato, A. (2008). Life cycle assessment of photovoltaic electricity generation. Energy, 33, pp. $224-232$.

[16] Morvay, Z.K.; Gvozdenac, D.D. (2008). Applied Industrial Energy and Environmental Management, John Wiley and Sons, Ltd, Publication, ISBN 978-0-470-69742-9, Wiltshire, Great Britain.

[17] Green Rhino Energy, Manufacturing Silicon, Available online: http://www.greenrhinoenergy.com/solar/technologies/pv_manufacturing.php

[18] Tsec, Solar Module/Cell Manufacturing Process Introduction, Available online at: http://www.tsecpv.com/englobal/solar_knowledge/index/zero_house_02

[19] Gintung Energy Corporation, Module manufacturing process, Available online at: http://www.asectw.com/asec_Product_FlowProcess.html

[20] Andrejić, M.; Kilibarda, M. (2013). The problems of measuring efficiency in logistics, Proceedings of $1^{\text {st }}$ Logistics International Conference, Belgrade, Serbia , 28-30 November 2013. Available online at: http://logic.sf.bg.ac.rs/wp-content/uploads/Papers/ID-40.pdf

[21] Wang, W. Comparing the Energy Consumption of Logistics Chains in Traditional Retailing and E-commerce for Popular Products in the Context of China, Available online at: http://press-files.anu.edu.au/downloads/press/n1673/pdf/Wenjia_Wang.pdf

[22] Micieta, B.; Zavodska, L.; Rakyta, M.; Binasova, V. (2015). Sustainable concept for green logistics and energy efficiency in manufacturing, Chapter 33 in DAAAM International Scientific Book 2015, pp.391-400, B. Katalinic (Ed.), Published by DAAAM International, ISBN 978-3-902734-05-1, ISSN 1726-9687, Vienna, Austria, DOI: 10.2507/daaam.scibook.2015.33

[23] Chen, C. J. (2011). Physics of Solar Energy, John Wiley and Sons, Ltd, Publication, ISBN 978-0-470-64780-6, Hoboken, New Jersey.

[24] PV solar system diagrams, PV On-grid systems. Available online at: http://pvshop.eu/diagrams.html

[25] IRENA. (2016). End-of-life Management: Solar Photovoltaic Panels, ISBN 978-92-95111-99-8 (PDF, IRENA) Available online at: http://www.irena.org/DocumentDownloads/Publications/IRENA_IEAPVPS_End-ofLife_Solar_PV_Panels_2016.pdf 